\title{
Fiamme textures in volcanic successions: Flaming issues of definition and interpretation
}

\author{
Katharine F. Bull*, Jocelyn McPhie \\ ARC Centre of Excellence in Ore Deposits and School of Earth Sciences, University of Tasmania, Private Bag 79, Hobart, TAS 7001, Australia
}

Received 27 October 2006; received in revised form 29 March 2007; accepted 11 May 2007

Available online 24 May 2007

\begin{abstract}
Fiamme are aligned, "flame-like" lenses found in welded ignimbrite. Fiamme also occur in welded pyroclastic fall deposits, secondary welded pumice-rich facies, diagenetically altered and compacted non-welded, pumiceous, volcaniclastic facies and lavas. Fiamme can be formed in a variety of ways. The common genetic use of the term fiamme for pumice clasts that have undergone welding compaction is too narrow. "Fiamme" is best used as a descriptive term for elongate lenses or domains of the same mineralogy, texture and composition, which define a pre-tectonic foliation, and are separated by domains of different mineralogy, texture or composition. This descriptive term can be used regardless of the origin of the texture, and remains appropriate for flattened pumice clasts in welded ignimbrite.
\end{abstract}

(C) 2007 Elsevier B.V. All rights reserved.

Keywords: fiamme; pumice; welding; volcanic textures

\section{Introduction}

Widespread use of the term 'fiamme', Italian for 'flames', has ignited much confusion about its meaning in relation to interpretation of textures in volcanic rocks. Research focussing on the facies architecture of Late Silurian-Early Devonian submarine silicic volcanic successions in NSW, Australia, has uncovered several genetically different facies that display fiamme textures. The recognition of various origins has highlighted the

\footnotetext{
* Corresponding author. Present address: Alaska Volcano Observatory, DGGS, 3354 College Rd, Fairbanks, AK 99709, USA. Tel.: +1 907451 5055; fax: +1 9074515050 .

E-mail address: katharine.bull@alaska.gov (K.F. Bull).
}

need for a practical definition and a review of common volcanic facies in which fiamme occur.

As with many geological terms, 'fiamme' has acquired a genetic connotation, which, in many cases, is welding compaction in primary pyroclastic facies (e.g. Smith, 1960b; Ross and Smith, 1961; Ragan and Sheridan, 1972; Peterson, 1979; Sparks and Wright, 1979; Reedman et al., 1987; Scheepers and Nortje, 2000, Hildyard et al., 2000). However, fiamme can occur in diverse volcanic facies, and it is therefore important to separate the texture from the interpretation of its origin. The distinction is particularly significant in ancient and/ or altered volcanic successions in which genetic interpretations are not immediately obvious.

In this paper, eleven examples of facies that display fiamme textures are presented in order to illustrate the various processes which can produce fiamme textures. 
We have chosen examples where the genetic interpretation of the facies does not depend on the presence of fiamme. The aim is to show that there are several different origins for fiamme. Fiamme textures are not restricted to clastic rocks, and, alone, do not imply a unique interpretation of the host facies, nor of the process(es) of formation. We propose a descriptive definition of the term, which allows for diverse origins: fiamme are elongate lenses or domains, of the same mineralogy, texture and composition, which define a pre-tectonic foliation, and are separated by domains of different mineralogy, texture or composition. In many, but not all cases, the fiamme are clasts.

\section{Previous use of 'fiamme'}

The term 'fiamme' was defined by Ross and Smith (1961 p.4) as "the Italian name used to describe black glassy inclusions...which have a cross section shaped like a tongue of flame ${ }^{1}$. These are often several centimetres in length, but may range from microscopic size to several feet in length". These authors cited early references to the glassy lenses being pumice (e.g. Zavaritsky, 1947), but did not specify in their definition that the inclusions are or were pumice. Rast (1963) agreed that fiamme are pumice lenses, but noted that they are not restricted to ignimbrites and should not be used as an indicator of a pyroclastic origin. Similarly, Gibson and Tazieff (1967), based on observations of the Fantale ignimbrite, Ethiopia, and McBirney (1968), based on studies of ignimbrites in Honduras and Nicaragua, noted that the flattening of the pumice was probably not due to welding compaction. In the case of the Fantale ignimbrite, molten, volatile-rich, juvenile "lumps" were erupted with pumice, shards and crystals. Due to their low viscosity, the juvenile "lumps" flattened upon deposition (Gibson and Tazieff, 1967). In McBirney's (1968) Central American examples, glassy lenses occur in distinct layers within ignimbrites overlying watersaturated fluvial sediments. The diffusion of water from the sediments upward through the hot ignimbrite depressed the melting point of juvenile fragments and caused glassy lenses, or fiamme, to form after deposition of the ignimbrite (McBirney, 1968). The above examples led Gibson and Tazieff (1967) and McBirney (1968) to recommend that the term 'fiamme' revert to being a descriptive one, noting that substantiating the origin of the clasts, or the host rock for that matter, may not always be a simple task.

\footnotetext{
1 'fiamma' is singular for 'flame' in Italian, 'fiamme' is plural.
}

Fisher and Schmincke (1984, p. 215) used fiamme for dense, black, glassy lenses formed as the result of the collapse of porous pumice, but did not restrict the definition to pyroclastic facies. Branney and Sparks (1990, p. 919) also referred to fiamme as "strongly flattened pumice clasts", and noted that the presence of pumice clasts which are "flattened into a beddingparallel foliation (eutaxitic fabric)" (Branney and Sparks, 1990, p. 919), does not imply the cause of the flattening.

Many authors have questioned the definition of fiamme being restricted to flattened pumice clasts. As early as the 1940's, Matumoto (1943, cited in Ross and Smith, 1961) referred to spindles of obsidian within the Aso lava as fiamme, and Dorais et al. (1985) described fiamme textures produced by mafic inclusions within the Carpenter Ridge Tuff. McPhie et al. (1993) broadened the definition of fiamme from flattened pumice, to any elongate, lenticular juvenile clasts that define a pretectonic foliation. This definition attempted to cater for cases where pumice clasts in non-welded pumice-rich facies were altered and compacted during diagenesis, to create an apparent eutaxitic texture (e.g. McPhie et al., 1993; Gifkins et al., 2005). Hence, fiamme have been described in a variety of pyroclastic facies and altered volcanic facies and are certainly not restricted to welded ignimbrites.

Finally, it is impossible to address the definition of 'fiamme' without addressing the use of 'eutaxitic texture'. The initial term 'eutaxite' is attributed to Fritsch and Reiss (1868, cited by Ross and Smith, 1961, p. 4), and defined as "a volcanic rock composed of ejected fragments of different colours, and texture, as follows: 'The different fractions in general lie beside one another as streaks, or bands, and lenses in seemingly well ordered distribution". Despite this initial descriptive definition, eutaxite and eutaxitic texture are now used quite narrowly for cases where the 'various fractions' are fiamme, and, most commonly, the fiamme are flattened pumice clasts. Hence, the mainstream use of "eutaxitic texture" is in reference to the bedding-parallel alignment of fiamme in welded ignimbrite.

\section{Fiamme in welded pyroclastic facies}

Fiamme are most commonly recognised in welded pyroclastic facies, both in pyroclastic flow deposits (e.g. Smith, 1960a; Ross and Smith, 1961; Sparks et al., 1973; Wilson and Walker, 1982; Freundt et al., 2000), and in pyroclastic fall deposits (e.g. Sparks and Wright, 1979; Wolff and Wright, 1981; Mahood, 1984). Point and surface contacts between glassy juvenile fragments, such as pumice and bubble-wall shards, may sinter, anneal, or 
'weld' (Smith, 1960a; Riehle, 1973; Walker, 1983, Grunder and Russell, 2005). However, the temperature of the deposit, degree and timing of welding, and whether or not welding is associated with compaction or influenced by the presence of water, are factors that produce a spectrum of processes from syn-depositional agglutination to post-emplacement welding (Mahood, 1984; Branney and Kokelaar, 1992; Grunder and Russell, 2005; Grunder et al., 2005; Russell and Quane, 2005). In addition, in a single pyroclastic unit, the degree of welding and compaction may vary vertically and laterally (Smith, 1960b; Schmincke, 1974; Walker, 1983; Streck and Grunder, 1995; Grunder et al., 2005).

\subsection{Fiamme in welded ignimbrites}

Many welded ignimbrites characterised by fiamme have been described from both young and old volcanic successions worldwide (e.g. Tenerife, Fritsch and Reiss, 1868; Battleship Rock Tuff, Ross and Smith, 1961; Yellowstone Tuff, Boyd, 1961; the Bishop Tuff, Ragan and Sheridan, 1972; Sheridan and Wang, 2005; Garth Tuff, Howells et al., 1979; McArthur et al., 1998; Taupo Volcanic Zone, Marshall, 1935; Wilson et al., 1984; Aguas Calientes caldera, Petrinovic, 1999). Below we describe fiamme in the welded Owharoa ignimbrite, New Zealand, which is a non- to strongly welded ignimbrite with classic fiamme textures (Rabone, 1975; Braithwaite and Christie, 1996, this study).

The Owharoa ignimbrite is part of the Coromandel Volcanic Zone on the North Island of New Zealand, and Late Pliocene or mid-Pleistocene in age (Rabone, 1975; Braithwaite and Christie, 1996). The ignimbrite is undeformed, and consists of 4 layers: a lower, altered 'lenticulite' (breccia comprising lenticle-shaped clasts), at least several? metres thick (obscured base); a 4-m-thick, non-lenticle-bearing, fine-grained layer of predominantly flattened glass shards; a massive, 15-m-thick, jointed and devitrified layer; and, at the top, remnants of a second 'lenticulite' layer, which is weathered and poorly exposed, but at least $16 \mathrm{~m}$ thick. The upper and lower lenticulite layers appear to be similar. The lenticulite layers were described as containing "abundant flattened pumice lenticles in a matrix of flattened shards and fresh interstitial glass" (Rabone, 1975, p. 246). The nonlenticle-bearing ignimbrite consists of "flattened glass shards" (Rabone, 1975, p. 246), devitrified interstitial glass and uncommon crystals of plagioclase. Pumice clasts were not described.

In detail, the upper lenticulite contains $\sim 15$ modal $\%$ pale brown to black fiamme, $\sim 10-15$ modal $\%$ quartz and feldspar crystals $(2-7 \mathrm{~mm})$, and $\sim 2-5$ modal $\%$ angular lithic clasts $(2-15 \mathrm{~mm})$ (Fig. 1a). The fiamme are elongate, $2 \mathrm{~mm}$ to $2 \mathrm{~cm}$ long, and have length:thickness ratios of $4: 1$ to $\geq 15: 1$. They typically have ragged, feathery ends, wrap around lithic clasts and crystals, and are aligned parallel to bedding. The fiamme contain sparse quartz and/or plagioclase phenocrysts, and have an internal striated or fibrous texture that is parallel to the clast elongation direction and bedding, and interpreted to be compacted tube vesicle texture. There are also angular, equant, tube pumice clasts, up to $3 \mathrm{~cm}$ in diameter, in which the tube vesicles are perpendicular to bedding.

The matrix of the upper lenticulite consists of aligned and variably deformed, $0.05-0.1 \mathrm{~mm}$, glassy bubblewall shards, and glass (Fig. 1b). Few cuspate shard shapes remain, and the ends of the shards are round and
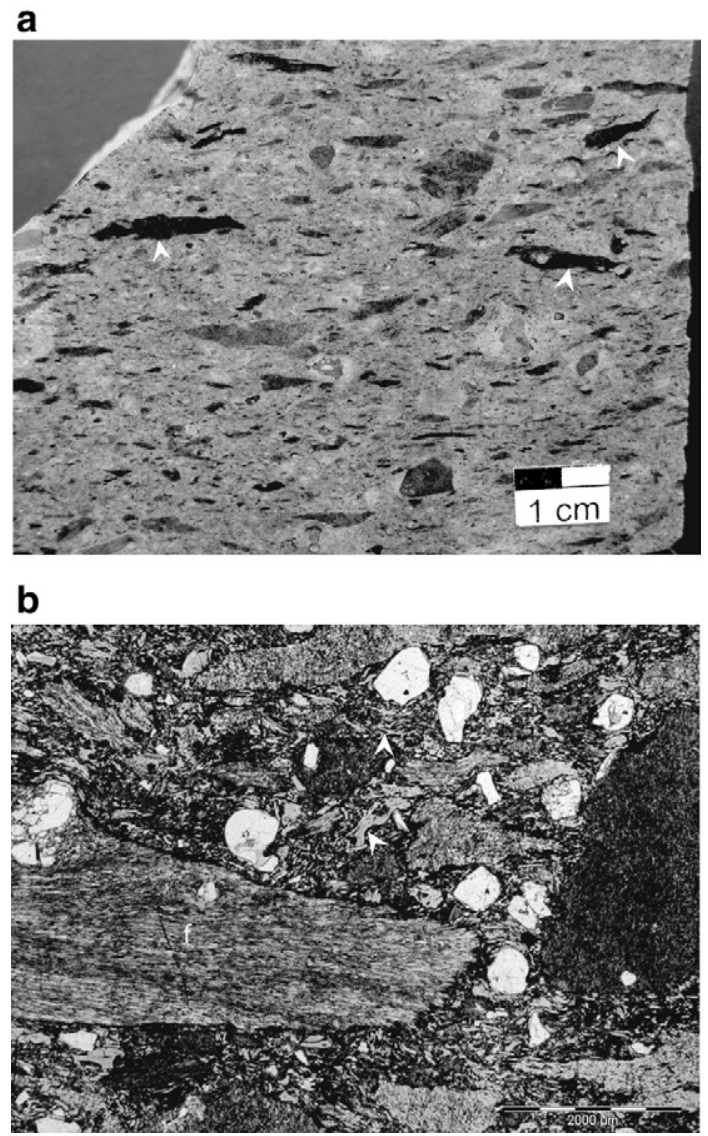

Fig. 1. Owharoa Ignimbrite, Coromandel Volcanic Zone, North Island of New Zealand. a. Hand sample of welded ignimbrite (Upper Lenticulite). The fiamme (arrows) are dark glassy lenses formed by welding compaction of juvenile pumice clasts. b. Photomicrograph of sample in a. Relic tube vesicles are visible in the fiamme (f). Bubblewall shards (arrows) in the matrix are flattened, subparallel to the fiamme foliation. Scale bar is $2 \mathrm{~mm}$. Plane polarised light. 
smooth. Pumiceous shards in the matrix are $\sim 0.5 \mathrm{~mm}$, partly devitrified, and in places wrap around crystals. Elongate vesicles in these pumiceous shards are commonly, but not consistently, parallel to the fiamme foliation and to bedding.

\subsection{Welded pyroclastic fall deposits}

Welding compaction of juvenile fragments can also occur in pyroclastic fall deposits. Well-known examples include the Askja Tuff, Iceland (Sparks and Wright, 1979), pyroclastic facies on Komagatake Volcano, Japan (Healy, 1973; Katsui et al., 1975; Nakagawa et al., 2003), the pyroclastic facies on Pantelleria, Italy (Sparks and Wright, 1979; Wright, 1980; Wolff and Wright, 1981; Mahood, 1984), and the Therasia tuff, Greece (Sparks and Wright, 1979). The Therasia tuff, referred to as part of the Cape Riva Tuff (rp6) by Druitt (1985) and Druitt et al. (1999), is exposed on eastern Therasia Island within Santorini caldera. The tuff was described by Sparks and Wright (1979) as a 1-m- to 1.7-m-thick, compositionally mixed (dacitic and andesitic), well-sorted (matrix-poor) deposit with non-welded to welded domains. Welding took place over an area of $\sim 6 \mathrm{~km}^{2}$. Non-welded portions consist of well-sorted pumice lapilli, and the unit displays mantle bedding. The densely welded and compacted zones contain black, glassy and phenocryst-rich fiamme, with "flattening ratios" (sic) ranging from 14:1 to 26:1, and they exhibit well-developed eutaxitic texture. Domains described as partially welded contain pumice lapilli which are slightly deformed to undeformed (Sparks and Wright, 1979).

\section{Fiamme in secondary welded pumice-rich facies}

Pumice-rich clastic facies in contact with hot lavas or intrusions can be reheated and undergo welding compaction, or 'fusion' (e.g. Ross and Smith 1961; Christiansen and Lipman, 1966; Schmincke, 1967; McPhie and Hunns, 1995). In many cases, the fiamme produced by secondary welding of pumice-rich clastic facies are virtually indistinguishable from fiamme in conventional primary welded pyroclastic facies.

An example of fiamme texture due to secondary welding occurs in Early Permian submarine pumicelithic breccias at Mt. Chalmers, Queensland (McPhie and Hunns, 1995). The pumice-lithic breccia units are very thick units $(\geq 100 \mathrm{~m})$, and are characterised by sharp bases, massive to graded, coarse, lower divisions and diffusely stratified, fine, upper divisions. They consist of abundant, well-preserved (though devitrified), randomly oriented tube pumice clasts and are locally interbedded with siltstone beds that contain in situ marine fossils (McPhie and Hunns, 1995).

The pumice-lithic breccia is intruded by andesite sills. Close to the sills (within $\sim 3 \mathrm{~m}$ ), there is gradation from randomly oriented pumice clasts to aligned fiamme that wrap around lithic clasts (Fig. 2). The fiamme are consistently aligned parallel to the breccia-andesite contacts. In addition, spherical amygdales and spherulites, and undeformed micropoikilitic texture are present in the strongly flattened pumice clasts. McPhie and Hunns (1995) concluded that the fiamme were originally non-welded glassy pumice clasts that underwent high-temperature secondary welding and compaction adjacent to the andesite sills. Compaction was followed by secondary vesiculation (to form amygdales) and crystallisation (to form spherulites and micropoikilitic texture) of the hot glass.

\section{Fiamme in non-welded, pumiceous, volcaniclastic facies}

Fiamme occur in a variety of non-welded, pumiceous volcaniclastic facies, including submarine syn-eruptive

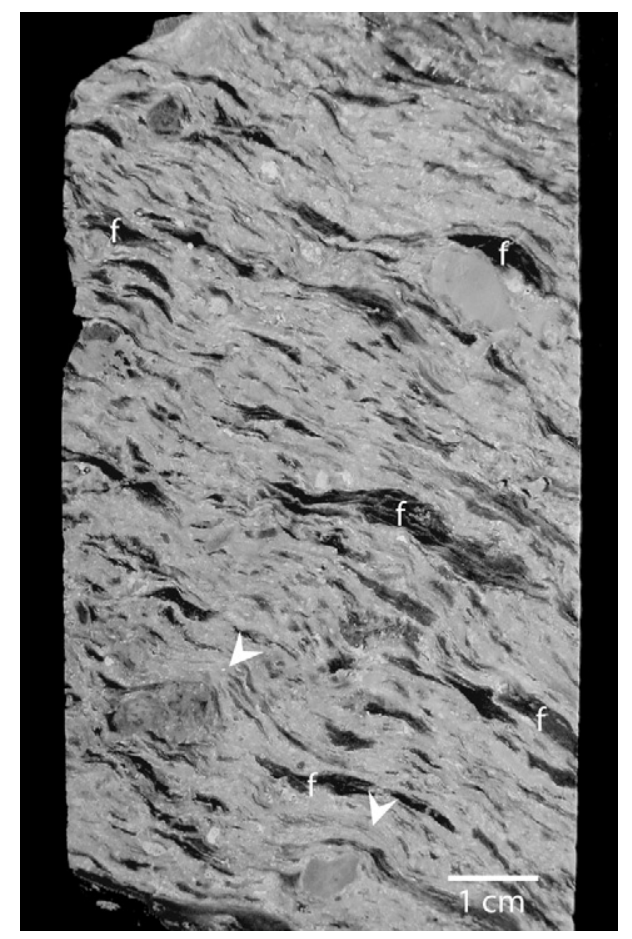

Fig. 2. Fiamme in pumice-lithic breccia in the Berserker Beds, Mt. Chalmers, Queensland (DDH MCD-7, $184.3 \mathrm{~m}$ ). Dark grey wispy fiamme (f) dominate the rock texture, and wrap around lithic clasts (arrows). In this case, fiamme were formed as a result of secondary welding and compaction of pumice clasts in pumice breccia adjacent to andesite sills (McPhie and Hunns, 1995). 
gravity current deposits, submarine water-settled fall deposits, and subaerial non-welded pyroclastic flow and fall deposits. The fiamme may be unaltered or uncompacted, elongate to lenticular juvenile clasts, or they may be former pumice clasts that have been diagenetically compacted (e.g. Fiske, 1963, 1969; Allen, 1990; Allen and Cas, 1990; Gifkins et al., 2005). Some examples are described below.

\subsection{Submarine syn-eruptive gravity current deposits}

The Middle to Late Cambrian Mount Read Volcanics (MRV), western Tasmania, include many thick and extensive units of non-welded fiamme-bearing pumice breccia. The MRV are a submarine, rhyolitic to basaltic, volcanic succession intercalated with non-volcanic and mixed-provenance sedimentary facies, and are intruded by Cambrian and Devonian granites (Corbett, 1992; McPhie et al., 1993). The MRV host several polymetallic massive sulfide deposits (Large et al., 2001), and have been affected by early diagenetic alteration, lower greenschist grade regional metamorphism and local hydrothermal and syn-tectonic alteration (McPhie et al., 1993; Gifkins and Allen, 2001).

Beds of pumice breccia in the MRV are very thick (up to $150 \mathrm{~m}$ ) and massive to normally graded (McPhie et al., 1993; McPhie and Allen, 2003; Gifkins et al., 2005). Apart from pumice clasts, volcanic lithic clasts, intraformational sedimentary clasts and relic shards are also present in small amounts $(<10 \%)$. All the originally glassy components are now finely crystalline. The beds have sharp bases and consist of thicker coarser intervals in the lower part and thinner, finer, commonly thinly stratified intervals above. Their internal organisation and context suggest deposition from syn-eruptive, submarine water-supported pumice-rich gravity currents.

In single beds, there are both equant pumice clasts and fiamme (length:width ratios $\leq 20: 1$ ). The equant pumice clasts have well-preserved tube- and round-vesicle textures. The relic shards also display undeformed bubble-wall shapes. Secondary feldspar has replaced the glass that formed the vesicle walls and has also infilled vesicles (Gifkins et al., 2005). The fiamme are composed of chlorite or sericite and typically lack any recognisable primary internal textures. They were probably originally single, relatively large pumice clasts or groups of pumice clasts. The fiamme are aligned parallel to bedding and the fiamme foliation is overprinted by the regional cleavage.

Although the fiamme define a foliation similar to eutaxitic texture found in welded pyroclastic facies, the presence of abundant undeformed pumice and bubble- wall shards indicates that compaction was most likely diagenetic, rather than hot welding compaction (Gifkins et al., 2005). Early diagenetic alteration replaced the glass and sealed the vesicles of most pumice clasts, so they were preserved uncompacted. However, some pumice clasts (or groups of pumice clasts) were converted to weak, easily compacted phyllosilicatedominated assemblages, and now define the beddingparallel fiamme.

\subsection{Submarine water-settled pumice deposits}

Fiamme-bearing breccia facies in the Early Devonian, submarine Ural Volcanics, Australia (Bull and McPhie, 2006) has characteristics consistent with an origin involving water-settling of pyroclastic pumice. The Ural Volcanics are an intrabasinal, silicic volcanic succession dominated by domes and sills, but the succession includes pyroclastic facies as well. The fiamme occur in the fiamme-siltstone breccia facies (Fig. 3). The facies occurs as 10 - to 100 -m-long, $\leq 80$-m-thick screens within a partly extrusive, dacitic sill, and consists of 5-25\%, centimetre-to metre-long, rhyolitic fiamme within diffusely to distinctly stratified, moderately sorted, volcanic siltstone to fine-grained sandstone (Fig. 3a-c; Bull and McPhie, 2006).

The fiamme have length:width ratios of $3: 1$ to $\geq 10: 1$, and are elongate parallel to laminae in the siltstone. The fiamme contain 7-15 modal \% feldspar \pm quartz phenocrysts within groundmass of very fine-grained chlorite \pm sericite, quartz and feldspar. The fiamme exhibit a patchy internal foliation that is parallel to their long axis. The delicate, ragged, feathery margins of the fiamme are interlaced with the siltstone, and bedding in the siltstone is continuous to the margins of the fiamme (Fig. 3a,b).

The siltstone consists of plagioclase and quartz grains and locally contains undeformed, devitrified bubble-wall shard fragments and sub-mm size, devitrified, relic tube pumice fragments (Fig. 3d). The tube vesicles within the pumice clasts are delineated by bands of fine quartz and feldspar, alternating with chlorite bands. The small tube pumice fragments are randomly oriented, equant (length:width ratios 1:1 to 2:1), and angular with pointed terminations.

The elongate shape and strong, bedding-parallel alignment of the fiamme suggest that they were formerly porous clasts (pumice) that have undergone compaction. Because the matrix shards and fine pumice fragments are undeformed, and there is no textural evidence for hot emplacement such as annealed shards and fluidal relic pumice shapes, the compaction of the coarse pumice 


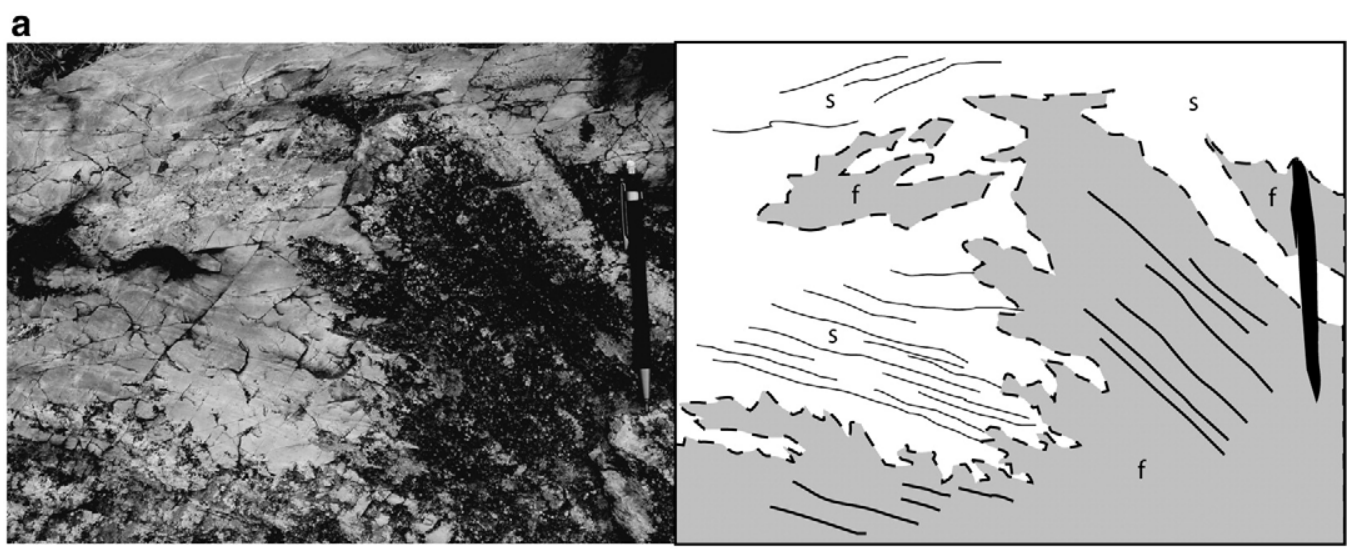

b

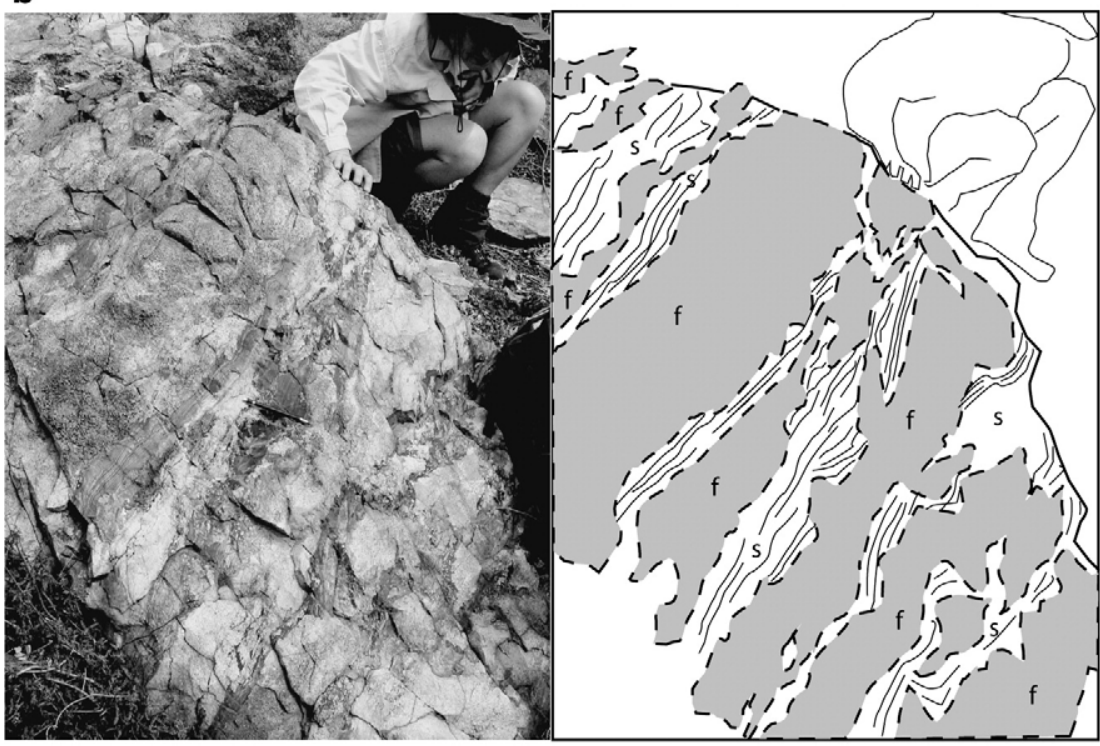

C

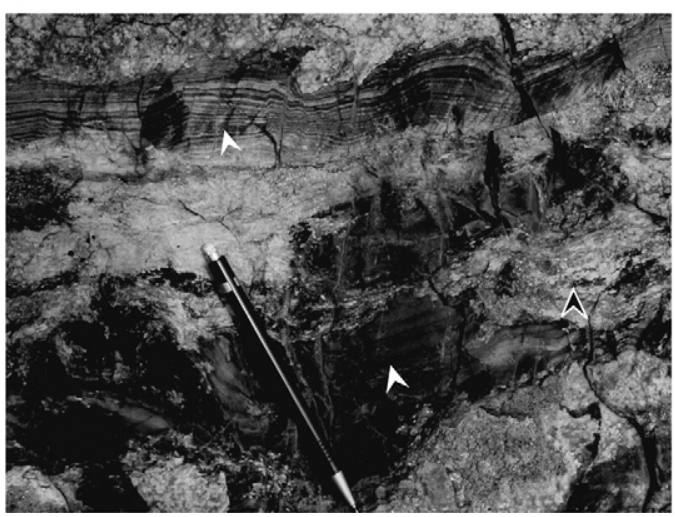

d

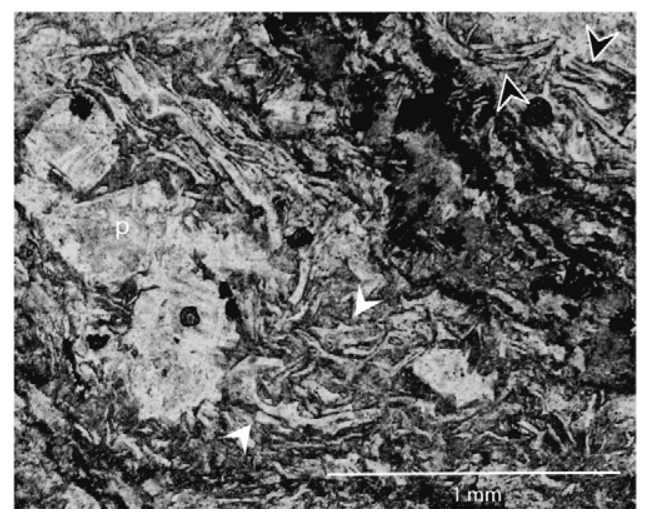

Fig. 3. Fiamme-siltstone breccia, Ural Volcanics, NSW. a) Fiamme (f), 10-100 cm long, have length:width ratios of 3:1 to $>10: 1$, and are parallel to bedding in the siltstone (s). Pencil is $14 \mathrm{~cm}$ long. b) Outcrop of fiamme-siltstone breccia. Drawing on right delineates $\sim 1$-m-long fiamme (f) in laminated, shard-rich siltstone (s) (426336E 6307692N). c) Delicate laminations in siltstone (white arrows) are continuous to fiamme. Black arrow points to foliation in fiamme caused by patchy relic tube vesicles. Pencil is $14 \mathrm{~cm}$ long. d) Photomicrograph of bubble-wall shards (arrows) in siltstone matrix of fiamme-siltstone breccia (427824E 6308904N). The matrix also includes crystals (p), and mm- to sub-mm-size tube pumice fragments (black arrow). Plane polarised light. Scale bar $=1 \mathrm{~mm}$. 
clasts was probably diagenetic, rather than hot welding compaction.

The strongly bimodal character of this facies, the continuity and undisturbed state of the bedding in the siltstone and the relatively good sorting of the siltstone support the interpretation that the fiamme-siltstone breccia facies consists of particles that settled from suspension in the water column - on one hand, fine $(<2 \mathrm{~mm})$ crystals, pumice and shards, and on the other, coarse $(\leq 1 \mathrm{~m})$, pumice clasts. Both grain populations could have been produced by an explosive eruption, the fine fraction being suspended because of the small size and low settling velocities of the clasts, and the coarse pumice clasts being temporarily buoyant. The clast assemblage and mode of deposition together indicate that this facies is a variety of water-settled fall.

\subsection{Subaerial non-welded pyroclastic fall deposits}

Branney and Sparks (1990) described fiamme textures in Recent pumice fall deposits on Sao Miguel, Azores. Trachytic plinian and sub-plinian pumice lapilli fall layers from the Sete Cidades caldera are interlayered with soils, exposed on sea cliffs near Vigia (Booth et al., 1978; Branney and Sparks, 1990). During soil formation, the soils penetrated to different extents into the pumice layers, between the pumice clasts, and the pumice clasts then altered to halloysite and other clay minerals. The soil-and-pumice deposits were then overlain by basalt lava. Altered pumice clasts were flattened by the lithostatic load, forming aligned, bedding-parallel lenticules, or fiamme, resembling eutaxitic texture in welded ignimbrites (Branney and Sparks, 1990). As in the MRV discussed above, it is thought that the alteration of the glassy pumice clasts to phyllosilicate minerals made them vulnerable to diagenetic compaction, resulting in fiamme textures.

\section{Fiamme in lavas}

The most rigorous test of the definition and use of the term 'fiamme' relates to the observation that fiamme textures are not restricted to clastic facies. Aligned, elongate, wispy lenses have been observed in both the coherent and autoclastic facies of felsic and intermediate lavas and domes (e.g. Allen, 1988; Dadd, 1992a; Sparks et al., 1993). The lenses may be defined by variation in the vesicularity (pumiceous versus dense) or crystallinity (crystalline versus glassy) of the groundmass. The textures are commonly enhanced by alteration and/or metamorphism. Patchy alteration of apparently uniformly porphyritic coherent lava can also create texturally and/or mineralogically distinct lenses. Some examples are described below.

\subsection{Welded autobreccia}

Sparks et al. (1993) described fiamme texture in autoclastic breccia associated with the margins of the Tieton Andesite in Washington, USA, and the Lascar andesite in Chile. Both autobreccias are monomictic and have matrix-supported (matrix defined here as $<2 \mathrm{~mm}$ ) and clast-supported domains. There is a range in welding from point-welding at clast-clast contacts, to dense welding, where variably shaped clasts lie within a black, dense and glassy matrix (Sparks et al., 1993). The densely welded domains occur in welded basal breccias (Tieton andesite) and in levee breccias (Lascar andesite). Within the Lascar breccias, the original clast shape has been lost and "most of the clasts have been deformed into lenticular glassy lenses of fiamme" (Sparks et al., 1993, p.898). The clasts are elongate and fluidal, and have a relatively high length:width ratio $(\geq 5: 1)$. In densely welded sections, plastic deformation has affected the finest clasts (a few hundred microns; Sparks et al., 1993).

The authors concluded that the breccias were originally autobreccias that were overridden by new, hot lava and deformed in areas of highest shear stress. In the case of the Lascar breccias, lava clasts accumulated in extension fractures or crevasses along the lava flow margins, including the lava levées. The crevasses later closed and the trapped clasts were heated and deformed. In the Tieton breccias, marginal and flow-front breccias were reincorporated into the basal region where they underwent high shear stress and advective reheating, causing welding (Sparks et al., 1993). Thus, clasts in autobreccia at the margins of lavas can be welded, deformed into lenticular shapes and aligned, creating fiamme.

Similar textures have been observed in the Pleistocene Ngongotaha Rhyolite, New Zealand, in which "lenticulite breccia" is interlayered with variably devitrified, continuously flow-banded rhyolite (Dadd, 1992b). The elongate lenticular lenses consist of obsidian and "range from massive with sparse spherulites and perlitic cracking to clasts 'veined' with devitrified rhyolite and having a wispy texture" (Dadd, 1992b, p.44). The lenses are strongly aligned and resemble fiamme (Fig. 4). Dadd (1992b) concluded that the fiamme textures were defined by patchy spherulitic and/or devitrified domains versus obsidian domains in otherwise coherent lava. We have observed that the phenocrysts are locally broken and not continuous past 


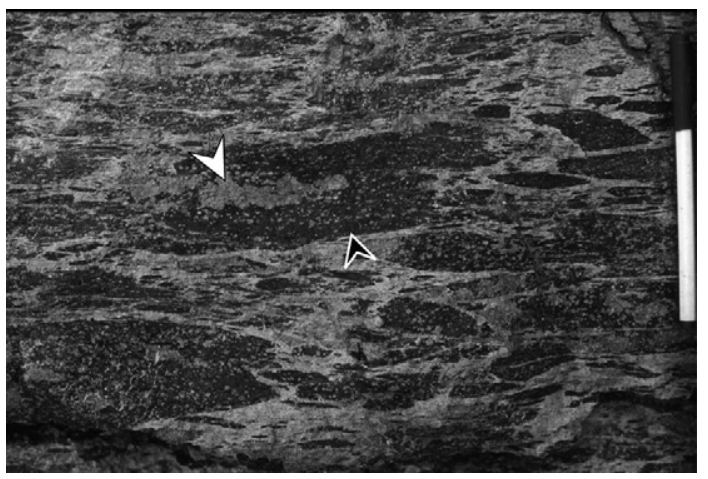

Fig. 4. Ngongotaha Rhyolite, North Island of New Zealand. Elongate clasts of flow-banded obsidian (black arrow) and spherulitic domains (white arrow) define fiamme textures in welded rhyolite autobreccia. Pen is $15 \mathrm{~cm}$ long.

clast margins. The clasts have sharp boundaries and are commonly flow-banded and rotated. Small clasts $(<1 \mathrm{~mm})$ are angular and blocky, and large clasts are also typically angular. Some clast boundaries are intricately interfingered and overlapping. The distinct and angular clast margins and the presence of rotated, flow-banded clasts suggest that at least locally, the Ngongotaha lenticulite breccia is another example of a welded autobreccia.

\subsection{Pumiceous glassy vs. dense glassy domains in coherent facies}

The coherent facies of felsic lavas may exhibit fiamme texture defined by aligned pumiceous lenses. Examples occur in the Roche Rosse Rhyolite on the northeastern coast of Lipari, Italy. The rhyolite erupted at $\sim 730$ A.D. from the Monte Pilato volcanic centre and flowed $\sim 1 \mathrm{~km}$ northeast to the coast (Pichler, 1980; Crisci et al., 1991). The rhyolite has a flow-banded, highly vesicular pumiceous carapace up to $\sim 1$ m thick. The pumiceous carapace grades within centimetres into flow-banded coherent rhyolite, in which black, dense obsidian bands alternate with grey to pink spherulitic bands, and pale grey pumiceous bands and domains. Locally the pumiceous domains are lenses $1 \mathrm{~cm}$ to $\sim 20 \mathrm{~cm}$ long (length:width ratios are $\sim 3: 1$ to $\geq 14: 1$ ), and the vesicles are primarily elliptical and uncommonly spherical (Fig. 5). The lenses are aligned parallel to the flow bands, and have irregular, wispy ends, resembling fiamme. The abundance of the pumiceous lenses decreases towards the interior of the lava.

The fiamme in this case are pumiceous lenses rather than dense glass, and the presence of spherical to elliptical vesicles indicates the lenses have been stretched, but not compacted. The pumiceous lenses occur in a transitional zone between the flow-banded, pumiceous carapace, and the flow-banded obsidian of the lava interior. The lenses were probably formed as a result of non-laminar shear in this transitional zone, a consequence of the contrasts in rheology of the pumiceous and dense lava.

\subsection{Fiamme in altered coherent facies}

Fiamme textures occur in the coherent facies of a rhyolite ("10ra rhyolite") from the Siluro-Devonian submarine Ural Volcanics in NSW (Bull and McPhie, 2006). The 10ra rhyolite is at least $30 \mathrm{~m}$ thick and exposed in a $0.4 \mathrm{~km}^{2}$ outcrop area. It has a porphyritic texture and contains $\sim 7$ modal $\%, 0.5-1 \mathrm{~mm}$ plagioclase and $\sim 3$ modal $\%$ ferromagnesian phenocrysts altered to chlorite + epidote \pm sphene \pm opaques assemblages. The groundmass consists of fine-grained $(<0.1 \mathrm{~mm})$
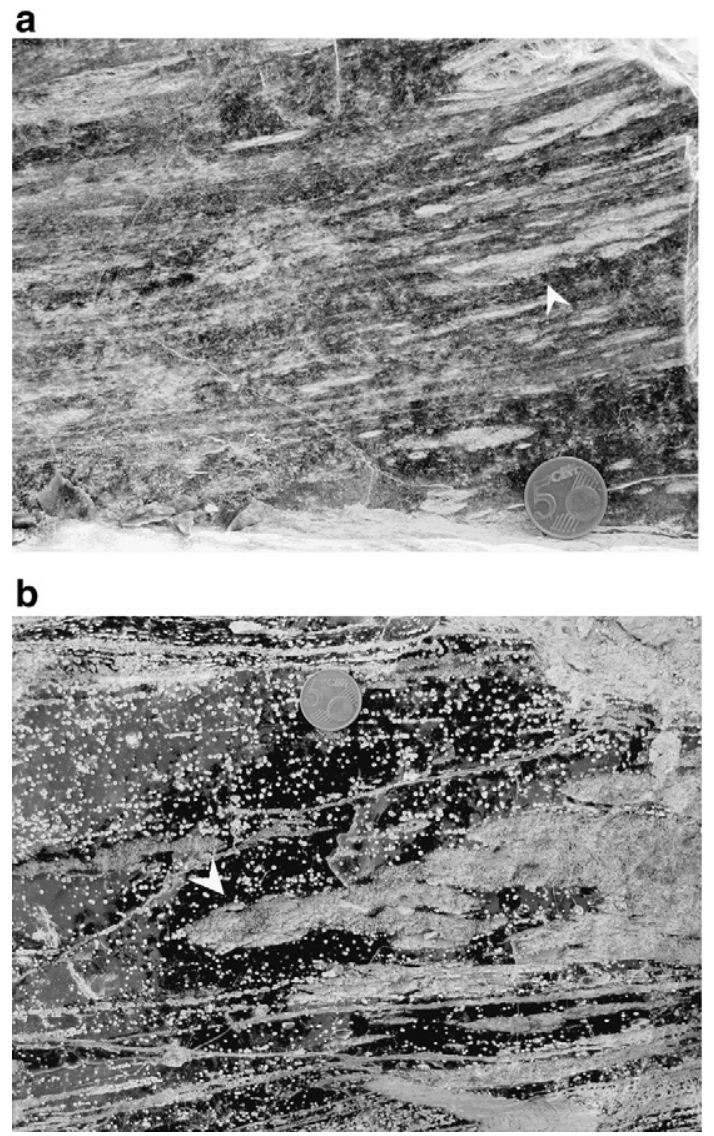

Fig. 5. Pumiceous and glassy domains in coherent rhyolite, Roche Rossi Rhyolite, Lipari, Italy. a). Pale grey pumiceous domains (arrow) define fiamme texture parallel to flow-bands. Coin diameter is $3 \mathrm{~cm}$. b) Pale grey pumiceous lenses (arrow) in obsidian have created fiamme texture. Flow-banding is defined by aligned spherulites in obsidian domains. Coin diameter is $3 \mathrm{~cm}$. 


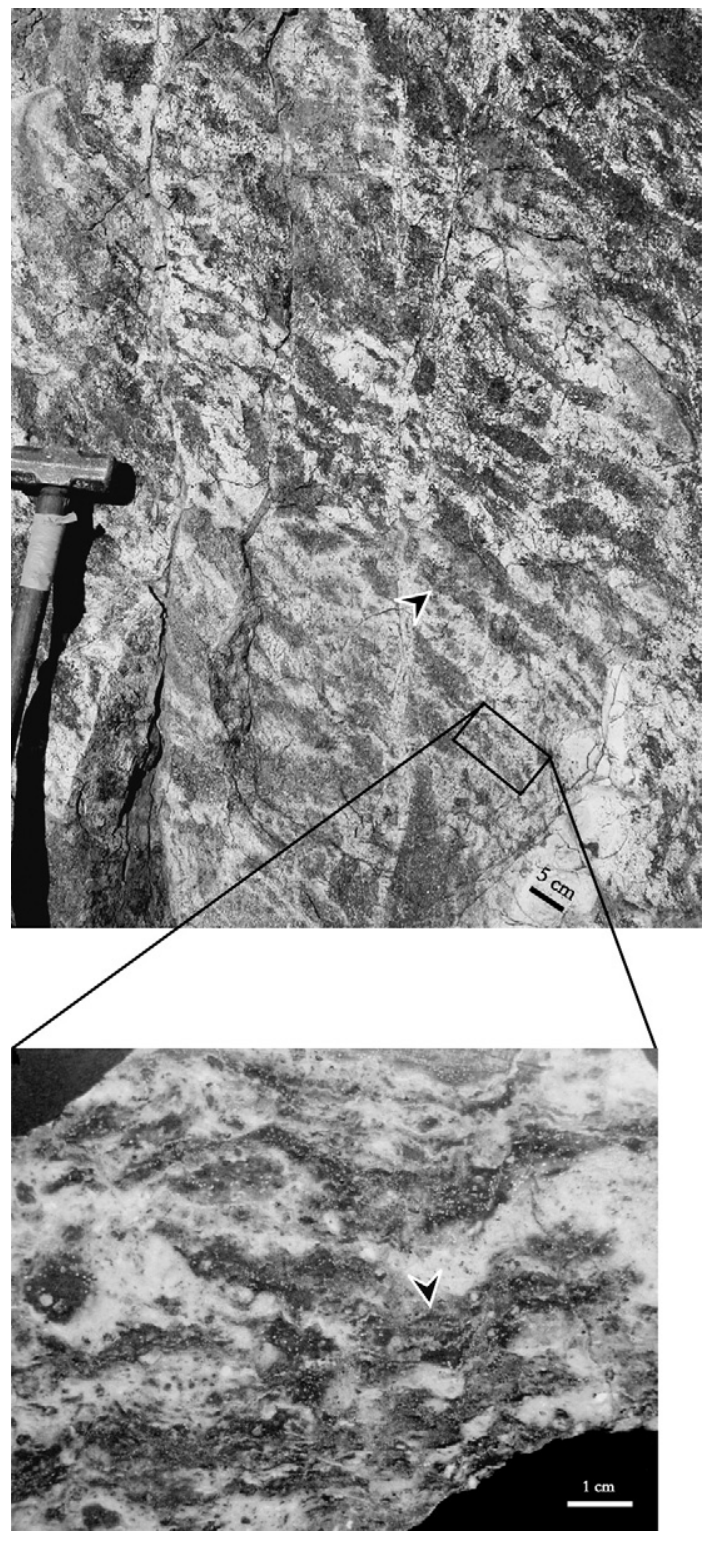

Fig. 6. Effects of patchy, two-phase alteration on coherent rhyolite (10ra Rhyolite), Ural Volcanics, NSW. a). Dark chlorite-sericite-altered domains (arrow) in pale, fine-grained quartz-feldspar-altered domains create fiamme texture. Uniform phenocryst distribution in both dark and pale domains, and fuzzy "clast" boundaries indicate that the fiamme-like lenses are due to patchy alteration in coherent rhyolite. b). Detail of a. Dark, elongate, chloritic lenses (arrow) are wispy in shape.

plagioclase and K-feldspar, with variable domains of sericite and chlorite. Feldspars are commonly albitealtered. The phenocrysts are glomeroporphyritic in places, but distributed fairly evenly throughout the rhyolite.

Close to the margin of the rhyolite, in a $\sim 20 \mathrm{~m} \times 20 \mathrm{~m}$ exposure, there are domains of green, wispy, elongate to slightly cuspate lenses $2-30 \mathrm{~cm}$ long, with an aspect ratio of $\sim 3: 1$ to $\geq 15: 1$, resembling fiamme (Fig. 6). The green domains contain plagioclase phenocrysts $(\sim 7$ modal $\%, 0.5-1 \mathrm{~mm})$, and a groundmass of weakly banded chlorite \pm sericite and very fine-grained quartz and feldspar (Fig. 6). The green domains occupy up to 70 modal $\%$ of the rock. The domains between the green lenses are plagioclase-phyric, but the groundmass is white, very fine-grained $(\sim 0.1 \mathrm{~mm})$ quartz, plagioclase and K-feldspar.

Close scrutiny of the green lenses and their margins suggests that they are not clasts, but instead result from the patchy distribution of contrasting groundmass alteration mineralogies - chlorite-rich versus chloritepoor - in otherwise coherent lava. The plagioclase phenocrysts commonly cross the boundaries of the green lenses, and they are uniform in modal percent,


Fig. 7. Crystalline and glassy domains in Roche Rossi Rhyolite, Lipari, Italy. a). Fiamme texture (arrows) occurs in a transitional zone between pale crystalline rhyolite (c) and black obsidian (obs). Coin diameter is $3 \mathrm{~cm} . \mathrm{b}$ ). Coalesced spherulites (pale) have left lenticular patches of obsidian (arrows), creating fiamme texture. Lens cap diameter is $6 \mathrm{~cm}$. 
distribution and size in both the green, chloritic and the white, non-chloritic domains. The margins of the green lenses are also indistinct. Finally, the only difference between the lenses and the surrounding domains is the groundmass mineralogy and texture.

Patchy, two-phase alteration is common in diagenetically altered volcanic rocks (Gifkins et al., 2005) and the patchy distribution of altered domains can be preserved and accentuated by regional metamorphism. The distribution of a particular alteration phase can be related to a pre-existing fracture network or other feature that controlled porosity and permeability. For example, in felsic lavas such as the 10a rhyolite, the control may have been the original distribution of crystalline versus dense glassy domains. In the Roche Rosse Rhyolite, Italy (described above), crystalline domains are composed of spherulites that have grown along flow bands within dense obsidian (Fig. 7). The spherulites vary in size from $0.1 \mathrm{~mm}$ to $\geq 2 \mathrm{~mm}$ in diameter. Where the spherulites are largest, they completely enclose obsidian lenses 1-7 mm long that have wispy to slightly cuspate shapes and resemble fiamme (Fig. 7).

Recognition of glassy or pumiceous lenses within the coherent facies of young, fresh, felsic lavas is relatively straightforward. However, in older lavas that have been altered, metamorphosed and/or deformed, the context may not be clear and interpretation of the textures can be more difficult. Lenses of pumice or glass will respond differently and have a distinct texture, mineralogy and composition compared to the adjacent dense or crystalline domains. The altered lenses can appear identical to conventional fiamme in compacted, pumice-rich clastic facies.

\section{Discussion and conclusions}

Fiamme texture occurs in both volcaniclastic facies and coherent parts of lavas, and in both subaerial and subaqueous volcanic successions. This texture is not uniquely diagnostic of any particular origin. Hence, the interpretation of fiamme-bearing facies requires additional information on the context, especially the contact relationships, geometry and internal organisation, and the style and intensity of any alteration. Given that fiamme textures are generated by a wide range of processes, we recommend a purely descriptive definition. We suggest that 'fiamme texture' be used to refer to multiple, aligned lenses that define a pre-tectonic foliation. The lenses, or fiamme, have the same mineralogy, texture and composition, and are separated by domains of different mineralogy, texture or composition. This definition allows 'fiamme' and 'fiamme texture' to be used for fresh volcanic facies such as welded ignimbrites and fall deposits, welded autobreccia and variably glassy and/or pumiceous coherent lava. Fiamme can also be used for variably altered pumice-rich clastic facies, and altered coherent lava, and, importantly, for facies where the context and origin are unknown. This proposal is not new (e.g. Gibson and Tazieff, 1967; McBirney, 1968; Branney and Sparks, 1990; Sparks et al., 1993), though the definition is, catering as it does for the wide variety of volcanic facies known to display fiamme.

The term 'eutaxitic texture' is well-established and, in general, used consistently in the literature for the foliation formed as a result of welding compaction of pumice fragments in hot pyroclastic deposits (e.g. Ross and Smith, 1961). It is a genetic term, reserved for a specific type of fiamme texture in cases where the origin of the texture has already been established.

In deformed volcanic successions, correct textural interpretation depends on distinguishing primary or early diagenetic textures from deformation-related textures. Early formed textures, generated during and soon after emplacement, are the most revealing of facies origin. Hence, the pre-tectonic nature (i.e. not obscured by regional deformation textures) of the foliation defined by fiamme is important. The foliations defined by fiamme are commonly parallel, or nearly parallel to, bedding or flow bands, and may be overprinted by or transposed into cleavage produced during regional deformation. However, at least locally, the two foliations may be parallel and impossible to distinguish.

\section{Acknowledgements}

This study is part of $\mathrm{PhD}$ research by KFB completed at the Centre for Ore Deposits Research (CODES-ARC Centre of Excellence) and School of Earth Sciences, University of Tasmania. Funding and in-kind support were provided by CODES, the Geological Survey of New South Wales, and a Society of Economic Geologists Hugh McKinstry grant.

\section{References}

Allen, R., 1988. False pyroclastic textures in altered silicic lavas, with implications for volcanic-associated mineralization. Economic Geology 83, 1424-1446.

Allen, R., 1990. Subaqueous welding, or alteration, diagenetic compaction and tectonic dissolution? IAVCEI International Volcanological Congress, Mainz, Germany Abstracts, p. 2.

Allen, R., Cas, R., 1990. The Rosebery controversy: distinguishing prospective ignimbrite-like units from true subaerial ignimbrites in the Rosebery-Hercules $\mathrm{Zn}-\mathrm{Cu}-\mathrm{Pb}$ massive sulfide district, Tasmania. 10th Australian Geological Convention, Geological Society of Australia Abstracts, vol. 25, pp. 31-32. 
Booth, B., Croasdale, R., Walker, G., 1978. A quantitative study of five thousand years of volcanism on Sao Miguel, Azores. Philosophical Transactions of the Royal Society of London. Series A 288, 271-319.

Boyd, F., 1961. Welded tuffs and flows in the Rhyolite Plateau of Yellowstone Park, Wyoming. Geological Society of America Bulletin 72, 387-426.

Braithwaite, R., Christie, A., 1996. Geology of the Waihi area; part sheets T13 and U13. Institute of Geological and Nuclear Sciences Geological Map, vol. 21. Institute of Geological and Nuclear Sciences, Lower Hutt, New Zealand. 64 pp.

Branney, M., Kokelaar, B., 1992. A reappraisal of ignimbrite emplacement: progressive aggradation and changes from particulate to non-particulate flow during emplacement of high-grade ignimbrite. Bulletin of Volcanology 54, 504-520.

Branney, M., Sparks, R., 1990. Fiamme formed by diagenesis and burial compaction in soils and subaqueous sediments. Journal of the Geological Society of London 147, 919-922.

Bull, K., McPhie, J., 2006. Facies architecture of the Early Devonian Ural Volcanics, New South Wales. Australian Journal of Earth Sciences 53 (6), 919-946.

Christiansen, R., Lipman, P., 1966. Emplacement and thermal history of a rhyolite flow near Fortymile Canyon, southern Nevada. Geological Society of America Bulletin 77, 671-684.

Corbett, K., 1992. Stratigraphic-volcanic setting of massive sulfide deposits in the Cambrian Mount Read Volcanics, Tasmania. Economic Geology 87, 564-586.

Crisci, G., Rosa, R., Esperanca, S., Mazzuoli, R., Sonnino, M., 1991. Temporal evolution of a three component system: the Island of Lipari (Aeolian arc, southern Italy). Bulletin of Volcanology 53, 207-221.

Dadd, K., 1992a. The Middle to Late Devonian Eden-ComerongYalwal Volcanic zone of Southeastern Australia: an ancient analogue of the Yellowstone-Snake River Plain region of the USA. Tectonophysics 214, 277-291.

Dadd, K., 1992b. Structures within large volume rhyolite lava flows of the Comerong Volcanics, southeastern Australia, and the Pleistocene Ngongotaha lava dome, New Zealand. Journal of Volcanology and Geothermal Research 54, 33-51.

Dorais, M., Whitney, J., Stormer, J., Kline, S., 1985. Mafic fiamme from the Carpenter Ridge Tuff, Central San Juan Volcanic Field: evidence for alkaline magmatism. Eos, Transactions of the American Geophysical Union 66 (46), 1152.

Druitt, T., 1985. Vent evolution and lag breccia formation during the Cape Riva eruption of Santorini, Greece. Journal of Geology 93, 439-454.

Druitt, T., Edwards, L., Mellors, R.M., Pyle, D.M., Sparks, R.S.J., Lanphere, M., Davies, M., and Barreirio, B., 1999. Santorini Volcano. Geological Society, London, Memoirs, 19. 165 pp., 1 mapsheet.

Fisher, R., Schmincke, H.-U., 1984. Pyroclastic Rocks. SpringerVerlag, Berlin. 472 pp.

Fiske, R., 1963. Subaqueous pyroclastic flows in the Ohanapecosh Formation, Washington. Geological Society of America Bulletin 74, 391-406.

Fiske, R., 1969. Recognition and significance of pumice in marine pyroclastic rocks. Geological Society of America Bulletin 80, 1-8.

Freundt, A., Wilson, C., Carey, S., 2000. Ignimbrites and block-andash flow deposits. In: Sigurdsson, H. (Ed.), Encyclopedia of Volcanoes. Academic Press, San Diego, pp. 581-600.

Fritsch, K., Reiss, W., 1868. Geologische beschreibung der Insel. Winterthur, Verlag von Wurster \& Co., Tenerife. 494 pp.
Gibson, I., Tazieff, H., 1967. Additional theory of origin of fiamme in ignimbrites. Nature 215 (5109), 1473-1474.

Gifkins, C., Allen, R., 2001. Textural and chemical characteristics of diagenetic and hydrothermal alteration in glassy volcanic rocks; examples from the Mount Read Volcanics. Economic Geology 96 (5), 973-1002.

Gifkins, C., Allen, R., McPhie, J., 2005. Apparent welding textures in altered pumice-rich rocks. Journal of Volcanology and Geothermal Research 142 (1-2), 29-47.

Grunder, A., Russell, J., 2005. Welding processes in volcanology: insights from field, experimental, and modeling studies. Journal of Volcanology and Geothermal Research 142 (1-2), 1-9.

Grunder, A., Laporte, D., Druitt, T., 2005. Experimental and textural investigation of welding: effects of compaction, sintering, and vapor-phase crystallization in the rhyolitic Rattlesnake Tuff. Journal of Volcanology and Geothermal Research 142 (1-2), 89-104.

Healy, J., 1973. Welded pyroclastic rock at Tongariro. New Zealand Journal of Geology and Geophysics 6, 712-714.

Hildyard, S., Cole, J., Weaver, S., 2000. Tikorangi ignimbrite; a 0.89 Ma mixed andesite-rhyolite ignimbrite, Matahana Basin, Taupo volcanic zone, New Zealand. New Zealand Journal of Geology and Geophysics 43 (1), 95-107.

Howells, M., Leveridge, B., Addison, R., Evans, C., Nutt, M., 1979. The Cape Curig Volcanic Formation, Snowdonia, North Wales: variation in ash-flow tuffs related to emplacement environment. In: Harris, A., Holland, C., Leake, B. (Eds.), The Caledonides of the British Isles Reviewed. Geological Society of London, London, pp. 611-618.

Katsui, Y., Yokoyama, I., Fujita, T., Ehara, Y., 1975. Komagatake report of the volcanoes in Hokkaido, part 4. Sapporo, Committee for Prevention of the Natural Disaster of Hokkaido, Sapporo. 194 pp.

Large, R., McPhie, J., Gemmell, J., Herrmann, W., Davidson, G., 2001. The spectrum of ore deposit types, volcanic environments, alteration halos and related exploration vectors in submarine volcanic successions: some examples from Australia. Economic Geology 96 (5), 913-938.

Mahood, G., 1984. Pyroclastic rocks and calderas associated with strongly peralkaline volcanic rocks. Journal of Volcanology and Geothermal Research 48, 143-172.

Marshall, P., 1935. Acid rocks of the Taupo-Rotorua volcanic district. Royal Society of New Zealand Monograph, vol. 64.

Matumoto, T., 1943. The four gigantic caldera volcanoes of Kyusyu. Japanese Journal of Geology and Geography 19, 59 (special).

McArthur, A., Cas, R., Orton, G., 1998. Distribution and significance of crystalline, perlitic and vesicular textures in the Ordovician Garth Tuff (Wales). Bulletin of Volcanology 60, 260-285.

McBirney, A., 1968. Second additional theory of origin of fiamme in ignimbrites. Nature 215 (5132), 938.

McPhie, J., Allen, R., 2003. Submarine, silicic, syn-eruptive pyroclastic units in the Mount Read Volcanics, western Tasmania: influence of vent setting and proximity on lithofacies characteristics. Geophysical Monograph 140, 245-258.

McPhie, J., Hunns, S., 1995. Pumiceous peperite in a submarine volcanic succession at Mount Chalmers, Queensland, Australia. Journal of Volcanology and Geothermal Research 88, 239-254.

McPhie, J., Doyle, M., Allen, R., 1993. Volcanic Textures: a Guide to the Interpretation of Textures in Volcanic Rocks. University of Tasmania Centre for Ore Deposit and Exploration Studies, Hobart. $198 \mathrm{pp}$. 
Nakagawa, M., Furukawa, R., Yoshimoto, M., 2003. Calderas and Active Volcanoes in Southwestern Hokkaido. The Volcanological Society of Japan, Hokkaido. 35 pp.

Pichler, H., 1980. The Island of Lipari. Rendiconti della Societa Italiana di Mineralogia e Petrologia 36, 415-440.

Peterson, D., 1979. Significance of the flattening of pumice fragments in ash-flow tuffs. In: Chapin, C.E., Elston, W.E. (Eds.), Ash-flow Tuffs. Special Paper, vol. 180. Geological Society of America, pp. 195-204.

Petrinovic, I., 1999. La Caldera de colapso del Cerro Aguas Calientes, Salta, Argentina: evolucion y esquema estructural. Acta Geologica Hisapnica 34 (2-3), 243-253.

Rabone, S., 1975. Petrography and hydrothermal alteration of Tertiary andesite-rhyolite volcanics in the Waitekauri Valley, Ohinemuri, New Zealand. New Zealand Journal of Geology and Geophysics 18 (2), 239-258.

Ragan, D., Sheridan, M., 1972. Compaction of the Bishop Tuff, California. Geological Society of America Bulletin 83, 95-106.

Rast, N., 1963. Letters: volcanic rocks of the Oramutia section, central Kenya. Geological Magazine 100 (1), 94-95.

Reedman, A., Park, K., Merriman, R., Kim, S., 1987. Welded tuff infilling a volcanic vent at Weolseong, Republic of Korea. Bulletin of Volcanology 49, 541-546.

Riehle, J., 1973. Calculated compaction profiles of rhyolite ash-flow tuffs. Geological Society of America Bulletin 84, 2193-2216.

Russell, J., Quane, S., 2005. Rheology of welding: inversion of field constraints. Journal of Volcanology and Geothermal Research 142 (1-2), 173-191.

Ross, C., Smith, R., 1961. Ash flow tuffs: their origin, geologic relations and identification. U.S. Geological Survey Professional Paper 366, 81.

Scheepers, R., Nortje, A., 2000. Rhyolitic ignimbrites of the Cape Granite Suite, southwestern Cape Province, South Africa. Journal of African Earth Sciences 31 (3/4), 647-656.

Schmincke, H.-U., 1967. Fused tuffs and peperites in South-Central Washington. Geological Society of America Bulletin 78, 319-330.

Schmincke, H.-U., 1974. Volcanological aspects of peralkaline silicic ash-flow tuffs. Bulletin of Volcanology 38, 594-636.
Sheridan, M., Wang, Y., 2005. Cooling and welding history of the Bishop Tuff in Adobe Valley and Chidago Canyon, California. Journal of Volcanology and Geothermal Research 142 (1-2), $119-144$.

Smith, R., 1960a. Ash flows. Geological Society of America Bulletin $71,795-842$.

Smith, R., 1960b. Zones and zonal variations in welded ash-flows. U.S. Geological Survey Professional Paper 354-F, 149-159.

Sparks, R., Wright, J., 1979. Welded air fall tuffs. Geological Society of America Bulletin, Special Paper 180, 155-166.

Sparks, R., Self, S., Walker, G., 1973. Products of ignimbrite eruptions. Geology 1 (3), 115-118.

Sparks, R., Stasiuk, M., Gardeweg, M., Swanson, D., 1993. Welded breccias in andesite lavas. Journal of the Geological Society of London 150, 897-902.

Streck, M., Grunder, A., 1995. Crystallization and welding variations in a widespread ignimbrite sheet; the Rattlesnake Tuff, eastern Oregon, USA. Bulletin of Volcanology 57, 151-169.

Walker, G., 1983. Ignimbrite types and ignimbrite problems. Journal of Volcanology and Geothermal Research 17, 65-88.

Wilson, C., Walker, G., 1982. Ignimbrite depositional facies: the anatomy of a pyroclastic flow. Journal of the Geological Society of London 139, 581-592.

Wilson, C., Rogan, A., Smith, I., Northey, D., Nairn, I., Houghton, B., 1984. Caldera Volcanoes of the Taupo Volcanic Zone, New Zealand. Journal of Geophysical Research 89 (B10), 8463-8484.

Wolff, J., Wright, J., 1981. Rheomorphism of welded tuffs. Journal of Volcanology and Geothermal Research 10, 13-34.

Wright, J., 1980. Stratigraphy and geology of the welded airfall tuffs of Pantelleria, Italy. Geologische Rundschau 69, 263-291.

Zavaritsky, A., 1947. The ignimbrites of Armenia. Akad. Nauk SSSR Izv., Ser. Geol, vol. 3, pp. 3-18. 